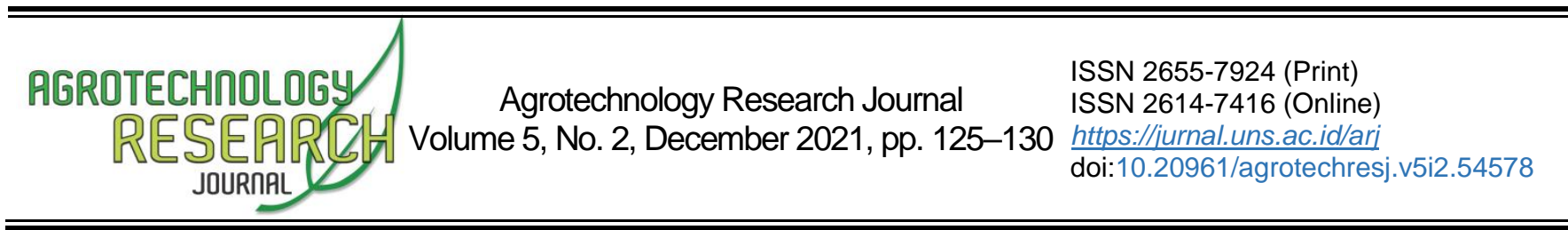

\title{
Efektivitas Cyhalofop-butyl Mengendalikan Gulma pada Budidaya Padi Sawah Tabela
}

\section{Effectiveness of Cyhalofop-butyl in Controlling Weeds in Direct Seeds Rice Cultivation}

\author{
Uum Umiyati ${ }^{1 *}$, Denny Kurniadie ${ }^{2}$, Deden $^{3}$ \\ ${ }^{1,2}$ Department of Agrotechnology, Faculty of Agriculture, Universitas Padjajaran, Bandung, Jawa Barat, Indonesia \\ ${ }^{3}$ Department of Agrotechnology, Faculty of Agriculture, Universitas Swadaya Gunung Jati Cirebon, Cirebon, Jawa Barat, \\ Indonesia
}

Received 22 August 2021; Accepted 24 December 2021; Published 31 December 2021

\begin{abstract}
High competition in the early growth phase will suppress growth and reduce rice yields. Presence of weeds in the rice field ecosystem needs to be controlled. Weed control with herbicides is more effective than other controls. This study aims to determine the effectiveness of the herbicide Cyhalofop-butyl in controlling weeds in the cultivation of direct seeds rice cultivation. The research was conducted in Sekaran village, Wonosari sub-district, Klaten district, Central Java. The method used was randomized block with seven treatments and four replications. The treatment consisted of a dose of the herbicide Cyhalofop-butyl $100{\mathrm{~g} . \mathrm{L}^{-1}}^{-}$with levels: $\left(50,75,100,125,150\right.$, and $\left.175 \mathrm{~L}^{-h^{-1}}\right)$, mechanical weeding and control (no weeding). The results showed that Cyhalofop-butyl at a dose of 50-175 L.ha-1 was effective in controlling the weeds of Echinochloa crus-galli, Leptochloa chinensis and other weeds at 3 weeks after application up to 6 weeks after application, without causing phytotoxicity effect on rice plants, herbicide Cyhalofop-butyl does not affect the growth and production of rice but reduces competition between weeds and rice

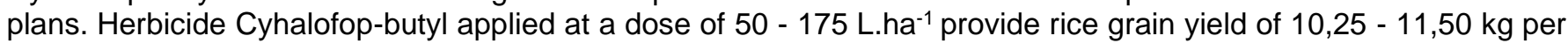
plot.
\end{abstract}

Keywords: competition; herbicide; Oryza sativa; phytotoxicity

Cite This As (CSE Style): Umiyati U, Kurniadie D, Deden. 2021. Efektivitas Cyhalofop-butyl mengendalikan gulma pada budidaya padi sawah tabela. Agrotechnology Res J. 5(2):125-130. https://dx.doi.org/10.20961/agrotechresj.v5i2.54578.

\section{PENDAHULUAN}

Sistem budidaya padi tabela sesuai dilakukan pada wilayah yang memiliki tenaga kerja sedikit, periode musim hujan pendek dan memiliki pengaturan air irigasi. Sistem ini dapat diterapkan pada lahan sawah yang mengandalkan air hujan sebagai sumber pengairan dan lahan kering dengan pengelolaan air dan penyiapan lahan yang baik (Biswas et al. 2020). Sistem tanam padai (Oryza sativa L.) tabela dapat mempercepat ketersediaan pangan. Tahun 2019 sampai 2020 peningkatan produksi nasional sebesar $54,60-54,65$ juta ton gabah kering (BPS 2020).

Budidaya padi tabela memiliki beberapa kendala, diantaranya membutuhkan pengolahan tanah dan air yang optimal. Hal tersebut bertujuan supaya benih yang ditanam tidak mati akibat terendam atau mati karena

${ }^{*}$ Corresponding Author:

E-Mail' : uum.umiyati@unpad.ac.id kekeringan. Kendala selanjutnya adalah kehadiran gulma yang tumbuh bersamaan dengan tanaman padi. Pertumbuhan gulma pada sistem tabela lebih padat dibandingkan dengan sistem tapin, karena penggenangan air tidak dilakukan pada awal penanaman (De Barreda et al. 2021; Utami et al. 2021). Pertumbuhan gulma yang lebih awal pada sistem padi tabela dapat mengurangi produksi padi yang menyebabkan kerugian. Gulma dapat menurunkan hasil padi sebesar 10-40\% (Chukwuka et al. 2007; Li et al. 2019). Hal ini disebabkan karena gulma dapat menyebabkan terjadi persaingan dengan padi dalam pemanfaatan air, cahaya, nutrisi, $\mathrm{CO}_{2}$ dan ruang untuk tumbuh (Chauhan et al. 2017; Akula et al. 2020; Manisankar et al. 2020; Li et al. 2021).

Padi sawah dengan sistem tanam tabela dapat menghasilkan hasil gabah lebih tinggi $(4,83$ t.ha-1) dibandingkan dengan padi sistem tapin (4,28 t.ha $\left.{ }^{-1}\right)$ jika bahan tanam dan cara budidaya serta pengendalian gulma yang digunakan tepat (Kaur dan Singh 2017). Petani Indonesia melakukan pengendalian gulma secara 
mekanis atau manual menggunakan tangan, lalandak (rotary weeder), pengendalian secara kultur teknis, biologis dan pengendalian secara kimia dengan menggunakan herbisida (Suryanto et al. 2020). Pengendalian mekanis mengalami kendala dalam ketersediaan tenaga kerja dan memerlukan waktu pengendalian yang lama (Purnomo dan Hasjim 2020). Upaya untuk mengatasi permasalahan tersebut mulai berkembang pengendalian gulma secara kimiawi dengan herbisida (Riar et al. 2015; Chandrasekar et al. 2017; Westwood et al. 2018). Pengendalian dengan herbisida memiliki keuntungan yaitu waktu pengendalian yang relatif lebih singkat dan tidak merusak perakaran tanaman (Deng et al. 2019). Namun, penggunaan herbisida secara terus-menerus dapat menyebabkan kesuburan tanah berkurang karena mikroorganisme terganggu (Ahmed et al. 2014). Namun, residu herbisida akan terdegradasi secara alami melalui dekomposisi fotokimia maupun terdegradasi secara biologi oleh mikroorganisme dan digunakan sebagai sumber energi, sehingga residu herbisida yang bersifat sistemis dan kontak tidak ditemukan di air irigasi maupun sungai (Ellezandi et al. 2017; Fang et al. 2020).

Salah satu senyawa kimia yang berpotensi sebagai bahan herbisida yaitu Cyhalofop-butyl 100 g.L-1 yang termasuk famili Aryloxyphenoxy propionate. Senyawa ini dapat menghambat dengan mode of action yaitu menghambat sintesa asam lemak, dengan ciri-ciri muncul bercak kuning pada daun gulma dalam waktu 23 hari hingga satu minggu, yang menyebabkan nekrosis dan kematian seluruh tanaman dalam waktu 2 hingga 3 minggu (Fang et al. 2020; Sen et al. 2021). Sifat dari herbisida tersebut adalah sistemik dan selektif serta diaplikasikan pasca tumbuh atau setelah gulma dan tanaman tumbuh. Cyhalofop-butyl 100 g.L-1 efektif mengendalikan gulma golongan rumput tetapi tidak mempengaruhi pertumbuhan tanaman padi (Wu et al. 2019). Teknik pengendalian gulma secara kimiawi sangat diperlukan untuk efisiensi pengendalian. Teknik pengendalian yaitu penentuan jenis herbisida, cara pemakaian, ketepatan dosis, dan waktu aplikasi. Tingkat dosis aplikasi menentukan efektivitas penggunaan herbisida untuk mengendalikan gulma, dan mempengaruhi efisiensi pengendalian secara ekonomi (Ellezandi et al. 2017; Moor et al. 2021). Penggunaan herbisida dengan bahan aktif yang sama secara terus menerus dalam waktu yang lama dapat mengakibatkan munculnya gulma yang resistan terhadap herbisida yang digunakan. Dengan demikian, penggunaan herbisida dengan dosis yang efektif akan terus ditingkatkan untuk menjaga efektivitas herbisida karena gulma yang resistan akan semakin sulit dikendalikan. Penelitian ini bertujuan untuk menentukan dosis efektif herbisida Cyhalofop-butyl dalam mengendalikan gulma rumput pada budidaya padi tabela.

\section{BAHAN DAN METODE}

Percobaan dilaksanakan dengan metode eksperimental yang dilakukan dari bulan Juli - Desember 2020 di Lahan petani Desa Sekaran, Kecamatan Wonosari, Kabupaten Klaten, Jawa Tengah, secara Geografis terletak 70 35' 25" LS - 70 39' 44,5" LS dan
1100 41' 42,4" BT - 1100 47' 25,8" BT, jenis tanah Regosol. Petakan berukuran $3 \mathrm{~m} \times 5 \mathrm{~m}$, jarak antar ulangan sekitar $1 \mathrm{~m}$, jarak tanam $25 \mathrm{~m}$ X $25 \mathrm{~m}$. Alat yang digunakan pada penelitian ini adalah sprayer semi otomatis dengan ipe nozel T-jet, gelas ukur, oven, timbangan, meteran, papan perlakuan, kamera, alat tulis, plastik dan cangkul. Bahan yang digunakan adalah benih padi varietas Ciherang, pupuk Urea, SP-36, dan $\mathrm{KCl}$, dan herbisida dengan bahan aktif Cyhalofop-butyl $100 \mathrm{~g} / \mathrm{l}$. Rancangan Acak Kelompok (RAK) dengan delapan perlakuan dan empat ulangan sehingga terdapat 32 perlakuan. Perlakuan yang diberikan yaitu tanpa pengendalian gulma (kontrol), penyiangan manual, dan berbagai dosis pemberian herbisida yang dapat dilihat pada Tabel 1, uji lanjut digunakan uji Beda Nyata Terkecil (BNT) pada tingkat kepercayaan 95\%. Aplikasi herbisida dilakukan satu kali pada saat tanaman berumur $10-15$ hari setelah tanam. Pengamatan yang dilakukan meliputi analisa vegetasi awal untuk mengetahui dominasi gulma, pengamatan bobot kering gulma yang dilakukan pada umur 3 dan 6 MSA (Minggu Setelah Aplikasi herbisida), pengamatan fitotoksisitas/keracunan tanaman padi akibat herbisida dilakukan 1, 2, dan 3 MSA (minggu setelah aplikasi), pengamatan jumlah anakan pada umur 3 dan 6 MSA dilakukan dan hasil gabah kering giling.

Tabel 1. Perlakuan dalam penelitian

\begin{tabular}{lc}
\hline Perlakuan & Dosis (L.ha-1) \\
\hline Cyhalofop-butyl $100 \mathrm{~g} / \mathrm{l}$ & 50 \\
Cyhalofop-butyl $100 \mathrm{~g} / \mathrm{l}$ & 75 \\
Cyhalofop-butyl $100 \mathrm{~g} / \mathrm{l}$ & 100 \\
Cyhalofop-butyl $100 \mathrm{~g} / \mathrm{l}$ & 125 \\
Cyhalofop-butyl $100 \mathrm{~g} / \mathrm{l}$. & 150 \\
Cyhalofop-butyl $100 \mathrm{~g} / \mathrm{l}$ & 175 \\
Penyiangan manual (2x) & 3 dan 6 Minggu Setelah \\
& Tanam
\end{tabular}

Kontrol

(tanpa pengendalian gulma)

\section{HASIL DAN PEMBAHASAN}

Tabel 2 menunjukkan data dari analisis vegetasi awal di lahan percobaan sebelum dilakukan aplikasi herbisida. Berdasarkan hasil analisa vegetasi yang dilakukan sebelum aplikasi herbisida bahwa lahan didominasi gulma golongan rumput seperti Leptochloa cinensis, Cyperus iria dan Echinochloa crus-galli. Leptochloa cinensis, Cyperus iria merupakan jenis gulma rumput dan Echinochloa crus-galli termasuk jenis gulma yang berdaun sempit. Herbisida yang digunakan untuk mengendalikan guma tersebut yaitu dengan bahan aktif Cyhalofop-butyl 100 g.L-1. Bahan aktif Cyhalofop-butyl 100 g.L-1 efektif mengendalikan gulma rumput sebesar 95,13\% (Chauhan et al. 2017). Hal ini disebabkan karena Cyhalofop-butyl menginduksi stres oksidatif dan sel imun pada tanaman (Cheng et al. 2021). 
Tabel 2. Analisis vegetasi gulma

\begin{tabular}{lc}
\hline Nama Spesies & $\begin{array}{c}\text { Sum Dominance Ratio } \\
(\text { SDR) (\%) }\end{array}$ \\
\hline Leptochloa cinensis & 25,96 \\
Cyperus iria & 17,96 \\
Echinochloa crus-galli & 17,96 \\
Monochoria vaginalis & 9,66 \\
Lymnocharis flava & 7,31 \\
Cyperus diformis & 7,96 \\
Fimbristylis miliacea & 4,96 \\
\hline
\end{tabular}

\section{Bobot Kering Gulma Leptochloa chinensis}

Tabel 3 menunjukkan bahwa pada pengamatan 3 Minggu Setelah Aplikasi (MSA), herbisida Cyhalofopbutyl 100 g.L.-1 pada dosis $50-175$ L.ha $^{-1}$ memiliki bobot kering Leptochloa chinensis yang paling kecil dan berbeda nyata dengan perlakuan kontrol serta perlakuan penyiangan manual, kecuali pada pengamatan $6 \mathrm{MSA}$ perlakuan dosis 50 L.ha ${ }^{-1}$ dengan perlakuan penyiangan manual menunjukkan perbedaan walaupun tidak nyata. Herbisida Cyhalofop-butyl 100 g.L-1 efektif dalam mengendalikan gulma tersebut. Hal ini terjadi karena Cyhalofop- butyl merupakan herbisida selektif dan dapat menekan pertumbuhan gulma Lepthocloa chinensis dengan menghambat sintesa asam lemak sehingga pertumbuhan gulma menjadi terhambat (Sudhana et al. 2018; Fang et al. 2020). Efektivitas herbisida Cyhalofop butyl dalam mengendalikan gulma rumput telah di teliti oleh beberapa peneliti. Herbisida dengan kandungan bahan aktif Cyhalofop butyl dapat mengendalikan gulma Leptochloa chinensis hingga $96 \%$ pada budidaya tanaman padi dengan sistem tanam benih langsung (Guntoro dan Fitri 2013; Jacob et al. 2014). Selain itu, bahan aktif Cyhalofop-butyl ini efektif mengendalikan gulma rumput (Aparna et al. 2017; Sen et al. 2021). Herbisida ini cenderung sedikit lemah terhadap jenis gulma berdaun lebar, karena jenis gulma ini memiliki lapisan lilin yang tebal untuk menghalangi absorpsi bahan aktif herbisida ke dalam jaringan sehingga menyebabkan jenis gulma ini sulit untuk dikendalikan (Sudhana et al. 2018).

Tabel 3. Pengaruh herbisida Cyhalofop-butyl terhadap bobot kering $L$. chinensis

\begin{tabular}{|c|c|c|}
\hline \multirow{2}{*}{$\begin{array}{l}\text { Cyhalofop-butyl } 100 \text { g.L-1 } \\
\left(\text { L.ha }^{-1}\right)\end{array}$} & \multicolumn{2}{|c|}{ Pengamatan (MSA) } \\
\hline & 3 & 6 \\
\hline 50 & $0,00 \mathrm{a}$ & $3,66 \mathrm{bc}$ \\
\hline 75 & $0,44 \mathrm{a}$ & $3,42 b$ \\
\hline 100 & $0,00 \mathrm{a}$ & $2,93 \mathrm{~b}$ \\
\hline 125 & $0,53 \mathrm{a}$ & $0,00 \mathrm{a}$ \\
\hline 150 & $0,84 \mathrm{~b}$ & $0,00 \mathrm{a}$ \\
\hline 175 & $2,40 \mathrm{c}$ & $2,23 b$ \\
\hline Penyiangan manual (2x) & $2,51 \mathrm{c}$ & $4,21 \mathrm{c}$ \\
\hline Tanpa penyiangan & $2,86 \mathrm{c}$ & $5,15 d$ \\
\hline
\end{tabular}

Keterangan: Huruf yang sama pada kolom yang sama menunjukkan tidak berbeda nyata menurut Uji BNT

\section{Bobot kering gulma E. crus-galli}

Herbisida Cyhalofop-butyl 100 g.L.-1 dapat menekan Echinochloa crus-galli sampai pengamatan 6 MSA. Tabel 4 menunjukkan bahwa pada 6 MSA herbisida Cyhalofop-butyl 100 g.L.-1 dengan dosis $100-175$ g.L-1 berpengaruh dalam mengendalikan gulma Echinochloa crus- galli. Perlakuan penyiangan manual dan kontrol Echinochloa crus-galli memiliki bobot kering yang lebih besar, sedangkan pada pengamatan 3 MSA herbisida

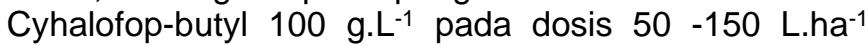
menunjukkan pengaruh yang berbeda nyata, hal tersebut membuktikan bahwa penggunaan herbisida dengan bahan aktif Cyhalofop-butyl 100 g.L-1 efektif dalam menghambat tumbuhnya gulma Echinochloa crus-galli. Bahan aktif Cyhalofop-butyl ini setelah diserap masuk ke dalam tubuh gulma akan ditranslokasikan dan bekerja menghambat kerja Asetil Koenzim-A Karboksilase, enzim ini bertindak dalam biosintesis asam lemak pada jenis rumput-rumputan. Penghambatan asam lemak menyebabkan kehilangan lemak dan kematian secara bertahap pada proses pembelahan sel di titik tumbuh (Fang et al. 2020; Scavo dan Mauromicale 2020).

Tabel 4. Pengaruh herbisida Cyhalofop butyl terhadap bobot kering E. crus-galli

\begin{tabular}{|c|c|c|}
\hline \multirow{2}{*}{$\begin{array}{l}\text { Cyhalofop-butyl } 100 \text { g.L }^{-1} \\
\left(\text { L.ha }^{-1}\right)\end{array}$} & \multicolumn{2}{|c|}{ Pengamatan (MSA) } \\
\hline & 3 & 6 \\
\hline 50 & $0,20 a$ & $3,47 \mathrm{bc}$ \\
\hline 75 & $0,28 a$ & $3,42 \mathrm{bc}$ \\
\hline 100 & $0,18 \mathrm{a}$ & $2,72 b$ \\
\hline 125 & $0,53 \mathrm{~b}$ & $0,00 \mathrm{a}$ \\
\hline 150 & $0,10 a$ & $0,00 \mathrm{a}$ \\
\hline 175 & $2,67 c$ & $2,91 b$ \\
\hline Penyiangan manual (2x) & $2,37 c$ & $4,84 \mathrm{C}$ \\
\hline Tanpa penyiangan & $2,55 \mathrm{c}$ & $6,38 d$ \\
\hline
\end{tabular}

Keterangan: Huruf yang sama pada kolom yang sama menunjukkan tidak berbeda nyata menurut Uji BNT

\section{Bobot kering gulma $C$. iria}

Hasil analisis statistik terhadap bobot kering gulma Cyperus iria pada Tabel 5 pengamatan 6 MSA menunjukkan perlakuan herbisida Cyhalofop-butyl 100 g/l dosis 50 - 175 L.ha ${ }^{-1}$ pada gulma Cyperus iria memiliki nilai yang tidak berbeda nyata dibandingkan dengan perlakuan penyiangan manual serta perlakuan kontrol. Hal ini menggambarkan bahwa herbisida yang digunakan kurang dapat mengendalikan gulma teki Cyperus iria hingga pengamatan terakhir. Herbisida Cyhalofop butyl sangat efektif dalam mengendalikan gulma rumput Echinochloa crus-galli. Beberapa penelitian menyebutkan bahwa herbisida Cyhalofop butyl terbukti efektif dalam mengendalikan gulma Echinochloa crus-galli (Aparna et al. 2017; MacLaren et al. 2020). Menurut Saha et al. (2021) herbisida Cyhalofop-butyl dapat mengendalikan gulma Echinocloa crus-galli yang resisten terhadap herbisida dengan bahan aktif imidazolinone. Herbisida berbahan aktif Cyhalofop butyl memiliki keefektifan yang cukup baik dalam mengendalikan gulma jenis rumput, tetapi pada gulma golongan teki kemampuan mengendalikannya 
berkurang seiring bertambahnya waktu pengamatan (Tabel 5). Li et al. (2021) menyebutkan bahwa herbisida seperti cyhalofop dan fenoxaprop, merupakan herbisida post emergence dapat mengontrol barnyard grass tetapi kurang memiliki aktivitas pada gulma jenis teki, karena jenis gulma ini memiliki ryzom yang dalam sehingga bahan aktif herbisida tidak dapat diabsorpsi dalam jaringan tersebut, menyebabkan jenis gulma ini sulit untuk dikendalikan dengan herbisida berbahan aktif Cyhalofop butyl.

Tabel 5. Pengaruh herbisida Cyhalofop-butyl terhadap bobot kering $C$. iria

\begin{tabular}{lcc}
\hline $\begin{array}{l}\text { Cyhalofop-butyl } 100 \text { g.L } \\
\left(\text { L.ha }^{-1}\right)\end{array}$ & \multicolumn{2}{c}{ Pengamatan (MSA) } \\
\cline { 2 - 3 } & $20,93 \mathrm{~b}$ & 38,14 \\
75 & $22,66 \mathrm{~b}$ & 24,23 \\
100 & $26,39 \mathrm{c}$ & 47,32 \\
125 & $15,64 \mathrm{a}$ & 49,74 \\
150 & $36,92 \mathrm{~d}$ & 52,86 \\
175 & $38,89 \mathrm{~d}$ & 45,76 \\
Penyiangan manual (2x) & $37,72 \mathrm{~d}$ & 52,78 \\
Tanpa pengendalian gulma & $20,95 \mathrm{~b}$ & 56,43 \\
\hline
\end{tabular}

Keterangan: Huruf yang sama pada kolom yang sama menunjukkan tidak berbeda nyata menurut Uji BNT

\section{Bobot kering gulma total}

Tabel 6. menunjukkan bahwa herbisida Cyhalofopbutyl dapat mengendalikan gulma total. Membuktikan bahwa herbisida Cyhalofop-butyl efektif digunakan untuk mengendalikan gulma padi khususnya gulma golongan rumput pada sistem padi tabela dan dapat menggantikan pengendalian gulma secara manual. Pengamatan tingkat keracunan tanaman dilakukan pada 1,2 dan 3 minggu setelah aplikasi, hal ini dilakukan untuk mengetahui pengaruh dosis herbisida terhadap fitotoksisitas atau keracunan tanaman. Berdasarkan hasil pengujian diketahui bahwa herbisida Cyhalofop butyl $100 \mathrm{~g} / \mathrm{l}$ dengan dosis 50-175 L.ha-1 tidak menimbulkan gejala keracunan atau fitotoksisitas pada tanaman padi (Tabel 7) Hal ini disebabkan karena herbisida Cyhalofop butyl 100 g.L-1 bersifat selektif sehingga herbisida ini hanya mengendalikan gulma di sekitar tanaman padi tetapi tidak menimbulkan pengaruh bagi pertumbuhan tanaman padi sawah sistem tanam benih langsung. Hal ini sesuai dengan Biswas et al. (2020) bahwa tanaman padi dapat menghasilkan enzim acetolase yang dapat mentoleransi herbisida menjadi tidak beracun.

\section{Jumlah anakan}

Tabel 8 menunjukkan bahwa herbisida Cyhalofopbutyl tidak mempengaruhi pertumbuhan tanaman atau meracuni hingga pengamatan 5 MSA. Hal tersebut tergambar dengan tidak ada beda nyata terhadap jumlah anakan tanaman padi pada semua perlakuan, namun jumlah anakan pada perlakuan kontrol lebih rendah dibandingkan perlakuan herbisida pada semua taraf dosis. Kemampuan herbisida menekan pertumbuhan gulma menyebabkan tanaman padi mampu berkompetisi dengan gulma dalam memanfaatkan unsur hara, air, cahaya dan sarana tumbuh untuk menunjang pertumbuhan anakan padi, sedangkan pada perlakuan kontrol tidak dilakukan pengendalian gulma sehingga terjadi kompetisi antara tanaman padi dengan gulma menyebabkan pertumbuhan anakan padi tertekan oleh adanya kompetisi (Lewis et al. 2016; Wahyudin et al. 2017; Chandio et al. 2020).

Tabel 6. Pengaruh herbisida Cyhalofop-butyl terhadap bobot kering gulma total

\begin{tabular}{lrr}
\hline $\begin{array}{l}\text { Cyhalofop-butyl } 100 \text { g.L-1 } \\
\left(\text { L.ha }^{-1}\right)\end{array}$ & \multicolumn{2}{c}{ Pengamatan (MSA) } \\
\cline { 2 - 3 } & \multicolumn{1}{c}{3} & \multicolumn{1}{c}{6} \\
\hline 50 & $81,18 \mathrm{c}$ & $136,20 \mathrm{c}$ \\
75 & $70,73 \mathrm{~b}$ & $106,38 \mathrm{~b}$ \\
100 & $56,65 \mathrm{a}$ & $80,03 \mathrm{a}$ \\
125 & $88,50 \mathrm{c}$ & $94,95 \mathrm{~b}$ \\
150 & $47,10 \mathrm{a}$ & $102,75 \mathrm{~b}$ \\
175 & $68,10 \mathrm{~b}$ & $79,73 \mathrm{a}$ \\
Penyiangan manual (2x) & $105,70 \mathrm{~d}$ & $177,00 \mathrm{~d}$ \\
Tanpa pengendalian gulma & $170,18 \mathrm{e}$ & $222,20 \mathrm{e}$ \\
\hline
\end{tabular}

Keterangan: Huruf yang sama pada kolom yang sama menunjukkan tidak berbeda nyata menurut Uji BNT

Tabel 7. Pengamatan keracunan padi akibat pengaruh herbisida Cyhalofop-butyl

\begin{tabular}{lccc}
\hline $\begin{array}{l}\text { Cyhalofop-butyl } 100 \text { g.L } \\
\left(\text { L.ha }^{-1}\right)\end{array}$ & \multicolumn{3}{c}{ Keracunan pada (MSA) } \\
\cline { 2 - 4 } 50 & $-{ }^{*}$ & - & 3 \\
75 & - & - & - \\
100 & - & - & - \\
125 & - & - & - \\
150 & - & - & - \\
175 & - & - & - \\
Penyiangan manual (2x) & - & - & - \\
Tanpa pengendalian gulma & - & - & - \\
\hline
\end{tabular}

*Keterangan: -: negatif atinya tidak menimbulkan keracunan

Tabel 8. Pengaruh herbisida Cyhalofop-butyl terhadap jumlah anakan padi

\begin{tabular}{lccc}
\hline $\left.\begin{array}{l}\text { Cyhalofop-butyl } 100 \text { g.L }^{-1} \\
\text { (L.ha }\end{array}{ }^{-1}\right)$ & \multicolumn{3}{c}{ Pengamatan ke (MSA) } \\
\cline { 2 - 4 } & 1 & 3 & 5 \\
\hline 50 & 15,19 & 22,00 & 26,80 \\
75 & 15,83 & 22,38 & 25,85 \\
100 & 15,94 & 20,38 & 29,40 \\
150 & 16,10 & 22,93 & 26,10 \\
150 & 16,83 & 20,68 & 26,10 \\
175 & 16,94 & 22,90 & 26,78 \\
Penyiangan manual (2x) & 15,08 & 19,53 & 25,58 \\
Tanpa pengendalian gulma & 14,90 & 18,68 & 22,45 \\
\hline
\end{tabular}

Keterangan: Huruf yang sama pada kolom yang sama menunjukkan tidak berbeda nyata menurut Uji BNT

\section{Bobot Gabah Kering Giling Padi Sawah}

Perlakuan herbisida Cyhalofop-butyl $100{\mathrm{~g} . \mathrm{L}^{-1}}$ pada semua taraf dosis yang digunakan berbeda nyata dengan penyiangan manual dan kontrol. Perlakuan pengendalian gulma dengan herbisida menunjukkan hasil yang tinggi yaitu sebesar 10,25 kg per petak - 11, $50 \mathrm{~kg}$ per petak dengan dosis 50-175 L.ha-1 (Tabel 9). Penurunan hasil akibat pertumbuhan gulma berhubungan dengan waktu kemunculan gulma (Shah dan Wu 2019; Martin et al. 
2021). Semakin cepat gulma muncul kompetisi antara gulma dengan tanaman semakin tinggi, sehingga menyebabkan serapan nutrisi tanaman padi rendah dan laju fotosintesis menurun selama fase reproduktif, menyebabkan fotosintat yang dihasilkan lebih sedikit dan dapat menurunkan bobot gabah kering giling (Ahmed et al. 2014; Farooq et al. 2017). Petak kontrol memiliki kerapatan gulma yang tinggi sehingga memberikan tekanan terhadap pertumbuhan tanaman padi dan pada akhirnya menyebabkan rendahnya hasil gabah kering giling yaitu sebesar $8,0 \mathrm{~kg}$ per petak. Pertumbuhan gulma yang tertekan oleh aplikasi herbisida tidak menyebabkan kompetisi, membantu tanaman padi lebih optimal memanfaatkan ketersediaan nutrisi di sekitarnya.

Tabel 9. Pengaruh herbisida Cyhalofop-butyl terhadap hasil gabah kering giling padi tabela

\begin{tabular}{lc}
\hline $\begin{array}{l}\text { Cyhalofop-butyl } 100 \text { g.L-1 } \\
\left(\text { L.ha }^{-1}\right)\end{array}$ & $\begin{array}{c}\text { Hasil Gabah Kering } \\
\text { Giling }(\mathrm{kg})\end{array}$ \\
\hline 50 & $10,50 \mathrm{c}$ \\
75 & $10,25 \mathrm{c}$ \\
100 & $10,88 \mathrm{~d}$ \\
125 & $11,50 \mathrm{~d}$ \\
150 & $11,00 \mathrm{~d}$ \\
175 & $11,38 \mathrm{~d}$ \\
Penyiangan manual (2x) & $9,88 \mathrm{~b}$ \\
Tanpa pengendalian gulma & $8,00 \mathrm{a}$ \\
\hline
\end{tabular}

Keterangan: Huruf yang sama pada kolom yang sama menunjukkan tidak berbeda nyata menurut Uji BNT

\section{KESIMPULAN DAN SARAN}

1. Herbisida Cyhalofop butyl 100 g.L ${ }^{-1}$ mampu mengendalikan gulma rumput Echinochloa crusgalli, dan Leptochloa chinensis dan tidak mempengaruhi pertumbuhan tanaman padi.

2. Perlakuan herbisida Cyhalofop-butyl 100 g.L-1 dengan dosis 50-175 L.ha-1 memberikan hasil gabah kering sebesar 10,25-11,50 kg gabah kering per petak contoh.

\section{DAFTAR PUSTAKA}

Ahmed S, Salim M, Chauhan BS. 2014. Effect of weed management and seed rate on crop growth under direct dry seeded rice systems in Bangladesh. PLoS One. 9(7). https://doi.org/10.1371/journal.pone.0101919.

Akula SH, Dass M, Surapaneni S, Balaravi P. 2020. Mapping of quantitative trait loci associated with resistance to brown planthopper in background of Swarna from a traditional variety PTB33. Euphytica. 4(216). https://doi.org/10.1007/s10681-020-02652-4.

Aparna KK, Menon M V., Prameela P. 2017. Efficacy of pre and post emergence herbicides on echinochloa spp. J Trop Agric. 55(1):91-95.

[BPS] Badan Pusat Statistik, 2020. Luas Panen dan Produksi Padi di Indonesia 2020 No. 22/03/Th. XXIV, 1 Maret 2021. Jakarta (ID): Badan Pusat Statistik.
Biswas B, Timsina J, Garai S, Mondal M, Banerjee H, Adhikary S, Kanthal S. 2020. Weed control in transplanted rice with post-emergence herbicides and their effects on subsequent rapeseed in Eastern India. Int J Pest Manag. 0(0):1-13. https://doi.org/10.1080/09670874.2020.1853276.

Chandio AA, Magsi H, Ozturk I. 2020. Examining the effects of climate change on rice production: case study of Pakistan. Environ Sci Pollut Res. 27(8):7812-7822. https://doi.org/10.1007/s11356019-07486-9.

Chandrasekar K, Muthukrishnan N, Soundararajan RP. 2017. ecological engineering cropping methods for enhancing predator, Cyrtorhinus lividipennis (Reuter) and suppression of planthopper, Nilaparvata lugens (Stal) in rice- effect of border cropping systems. Int $\mathrm{J}$ Curr Microbiol Appl Sci. 6(12):330-338. https://doi.org/10.20546/ijcmas.2017.612.039.

Chauhan BS, Matloob A, Mahajan G, Aslam F, Florentine SK, Jha P. 2017. Emerging challenges and opportunities for education and research in weed science. Front Plant Sci. 8(September):1-13. https://doi.org/10.3389/fpls.2017.01537.

Cheng B, Zou L, Zhang H, Cao Z, Liao X, Shen T, Xiong G, Xiao J, Liu H, Lu H. 2021. Effects of Cyhalofopbutyl on the developmental toxicity and immunotoxicity in zebrafish (Danio rerio). Chemosphere. 263(28):127849. https://doi.org/10.1016/j.chemosphere.2020.127849.

Chukwuka KS, Ogunyemi, Fawole I. 2007. ecological distribution of Tithonia diversifolia (Hemsl). A. Gray-A New Exotic Weed in Nigeria. J Bot Sci. 7(5):709-719.

De Barreda DG, Pardo G, Osca JM, Catala-Forner M, Consola S, Garnica I, López-Martínez N, Palmerín JA, Osuna MD. 2021. An overview of rice cultivation in spain and the management of herbicide-resistant weeds. Agronomy. 11(6):1-12. https://doi.org/10.3390/agronomy11061095.

Deng W, Cai J, Zhang J, Chen Yueyang, Chen Yongrui, Di Y, Yuan S. 2019. Molecular basis of resistance to ACCase-inhibiting herbicide Cyhalofop-butyl in Chinese sprangletop (Leptochloa chinensis (L.) Nees) from China. Pestic Biochem Physiol. 158(March):143-148.

https://doi.org/10.1016/j.pestbp.2019.05.004.

Ellezandi DF, Sembodo DRJ, Hamim H. 2017. Efikasi herbisida campuran atrazin dan mesotrion untuk mengendalikan gulma pada budidaya tanaman Jagung (Zea Mays L.). J Penelit Pertan Terap. 16(1):22-29. https://doi.org/10.25181/jppt.v16i1.72.

Fang J, He Z, Liu T, Li J, Dong L. 2020. A novel mutation Asp-2078-Glu in ACCase confers resistance to ACCase herbicides in barnyardgrass (Echinochloa crus-gali). Pestic Biochem Physiol. 168(June):104634.

https://doi.org/10.1016/j.pestbp.2020.104634.

Farooq M, Nawaz A, Ahmad E, Nadeem F, Hussain M, Siddique KHM. 2017. Using sorghum to suppress 
weeds in dry seeded aerobic and puddled transplanted rice. F Crop Res. 214(May):211-218. https://doi.org/10.1016/j.fcr.2017.09.017.

Guntoro D, Fitri TY. 2013. Aktivitas herbisida campuran bahan aktif Cyhalofop-butyl dan penoxsulam terhadap beberapa jenis gulma padi sawah. Bul Agrohorti.

https://doi.org/10.29244/agrob.1.1.140-148.

Jacob G, Menon M V, Abraham CT. 2014. Comparative efficacy of new herbicides in direct seeded rice. J Trop Agric 52. 52(2):174-177.

Kaur J, Singh A. 2017. Direct seeded rice: prospects, problems/constraints and researchable issues in India. Curr Agric Res J. 5(1):13-32. https://doi.org/10.12944/carj.5.1.03.

Lewis KA, Tzilivakis J, Warner DJ, Green A. 2016. An international database for pesticide risk assessments and management. Hum Ecol Risk Assess. 22(4):1050-1064.

https://doi.org/10.1080/10807039.2015.1133242.

Li L, Wang Y, Nie L, Ashraf U, Wang Z, Zhang Z, Wu T, Tian H, Hamoud YA, Tang $X$, et al. 2021. Deep placement of nitrogen fertilizer increases rice yield and energy production efficiency under different mechanical rice production systems. F Crop Res. 276(August https://doi.org/10.1016/j.fcr.2021.108359.

Li M, Li R, Zhang J, Liu S, Hei Z, Qiu S. 2019. A combination of rice cultivar mixed-cropping and duck co-culture suppressed weeds and pests in paddy fields. Basic Appl Ecol. 40:67-77. https://doi.org/10.1016/j.baae.2019.09.003.

MacLaren C, Storkey J, Menegat A, Metcalfe H, DehnenSchmutz K. 2020. An ecological future for weed science to sustain crop production and the environment. A review. Agron Sustain Dev. 40(4). https://doi.org/10.1007/s13593-020-00631-6.

Manisankar G, Ramesh T, Rathika S. 2020. Weed management in transplanted rice through pre plant application of herbicides: a review. Int $J$ Curr Microbiol Appl Sci. 9(5):684-692. https://doi.org/10.20546/ijcmas.2020.905.076.

Martin R, Chhun S, Yous S, Rien R, Korn C, Srean P. 2021. Survey of weed management practices in direct-seeded rice in. agronomy. 498(11). https://doi.org/10.3390/agronomy11030498.

Moor JC, Gore J, Catchot A, Cook D, Crow WD, Dodds DM, Sarver JM, Towles TB, Zurweller B. 2021. effect of imidacloprid and acephate for tobacco thrips (Thysonaptera: Thripidae) management on flumioxazin injured peanut. Peanut Sci. 48:6-14.

Purnomo WE, Hasjim S. 2020. Efektivitas dan selektivitas beberapa bahan aktif herbisida untuk mengendalikan gulma pada dua varietas tanaman kacang panjang (Vigna sesquipedalis L.). J Prot Tanam Trop. 1(2):48. https://doi.org/10.19184/jptt.v1i2.17917.
Riar DS, Tehranchian P, Norsworthy JK, Nandula V, McElroy S, Srivastava V, Chen S, Bond JA, Scott RC. 2015. Acetolactate synthase-inhibiting, herbicideresistant rice flatsedge (Cyperus iria): crossresistance and molecular mechanism of resistance . $\begin{array}{lll}\text { Weed } & \text { Sci. }\end{array}$ https://doi.org/10.1614/ws-d-15-00014.1.

Saha S, Munda S, Singh S, Kumar V, Jangde HK, Mahapatra A, Chauhan BS. 2021. Crop establishment and weed control options for sustaining dry direct seeded rice production in eastern India. Agronomy.

11(2):389. https://doi.org/10.3390/agronomy11020389.

Scavo A, Mauromicale G. 2020. Integrated weed management in herbaceous field crops. Agronomy. 10(4). https://doi.org/10.3390/agronomy10040466.

Sen S, Kaur R, Das TK, Raj R, Shivay YS. 2021. Impacts of herbicides on weeds, water productivity, and nutrient-use efficiency in dry direct-seeded rice. Paddy Water Environ. 19(1):227-238. https://doi.org/10.1007/s10333-020-00834-3.

Shah F, Wu W. 2019. Soil and crop management strategies to ensure higher crop productivity within sustainable environments. Sustainability. 11(1485):1-19. https://doi.org/10.3390/su11051485.

Sudhana A, Hardiastuti S, Padmini OS. 2018. Weeds control with herbicide dosage and frequency of pgpr toward growth and yield of paddy crops. Agrivet. 24(1):1-13.

https://doi.org/10.31315/agrivet.v24i1.4667.

Suryanto $P$, Faridah $E$, Nurjanto $H H$, Supriyanta, Kastono D, Putra ETS, Handayani S, Dewi AK, Alam T. 2020. Influence of siam weed compost on soybean varieties in an agroforestry system with kayu putih (Melaleuca cajuputi). Biodiversitas. 21(7):30623069. https://doi.org/10.13057/biodiv/d210725.

Utami S, Kurniadie D, Widayat D. 2021. Dinamika populasi gulma akibat aplikasi herbisida metil metsulfuron pada padi sawah sistem tanam pindah (tapin) dan tanam benih langsung (tabela). $\begin{array}{ll}\text { Agrikultura. } & 31(3): 174 .\end{array}$ https://doi.org/10.24198/agrikultura.v31i3.29231.

Wahyudin A, Ruminta R, Nursaripah SA. 2017. Pertumbuhan dan hasil tanaman jagung (Zea mays L.) toleran herbisida akibat pemberian berbagai dosis herbisida kalium glifosat. J Kultiv. 15(2):86-91. https://doi.org/10.24198/kultivasi.v15i2.11867.

Westwood JH, Charudattan R, Duke SO, Fennimore SA, Marrone $P$, Slaughter DC, Swanton C, Zollinger R. 2018. Weed management in 2050: perspectives on the future of weed science. Weed Sci. 66(3):275-285. https://doi.org/10.1017/wsc.2017.78.

Wu P, Chen Z, Zhang Y, Wang Y, Zhu F, Cao B, Wu Y, Li N. 2019. Rhodopseudomonas palustris wastewater treatment: Cyhalofop-butyl removal, biochemicals production and mathematical model establishment. Bioresour Technol. 282(November 2018):390-397. https://doi.org/10.1016/j.biortech.2018.11.087. 